\title{
THE ROLE AND IMPORTANCE OF
} OWNERS' PERCEPTIONS AND OPINIONS IN PRESERVING CONTINUITY BETWEEN GENERATIONS ON SLOVENIAN MOUNTAIN FARMS

\section{VLOGA IN POMEN GOSPODARJEVIH DOJEMANJ IN MNENJ ZA OHRANJANJE MEDGENERACIJSKE KONTINUITETE NA SLOVENSKIH HRIBOVSKIH KMETIJAH}

Boštjan »Kefo« Kerbler

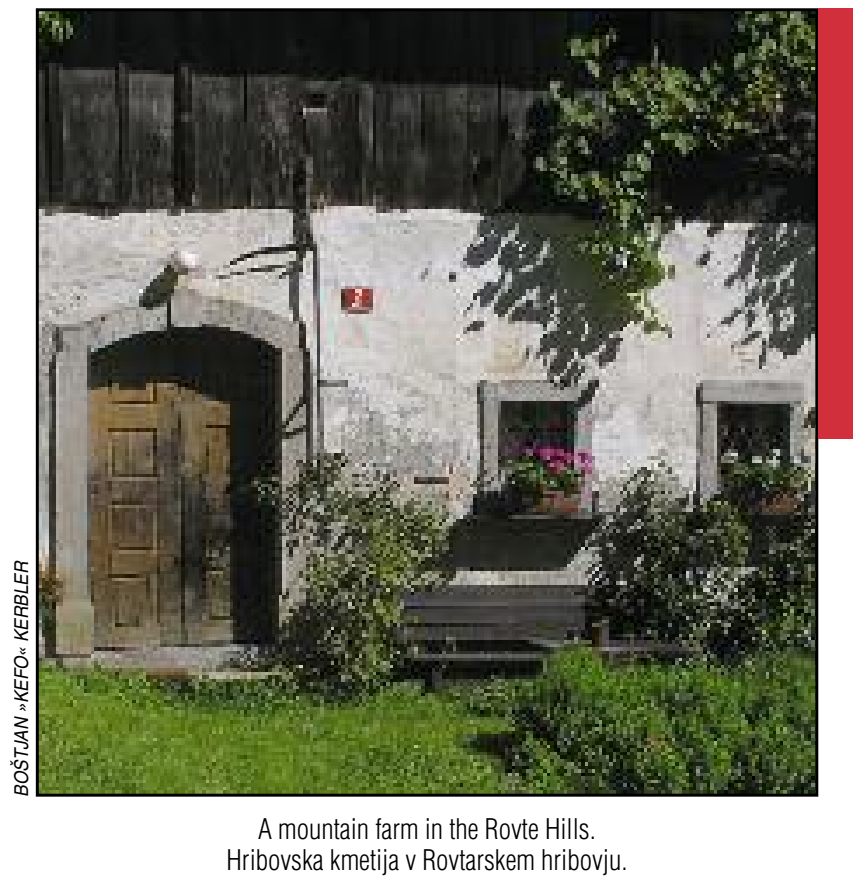




\section{The role and importance of owners' perceptions and opinions in preserving continuity between generations on slovenian mountain farms}

DOI: $10.3986 /$ AGS50102

UDC: 911.3(497.4):631.111(23.01)

COBISS: 1.01

ABSTRACT: Family farms are characterized by the fact that they are passed down within the family from one generation to the next. In this way, the orientation of parents and especially farm owners is also passed on to children. With regard to this characteristic, this paper proceeds from the hypothesis that owners' beliefs, opinions, and perceptions have an important impact on farm succession in Slovenia. It has been established that an owner's positive attitude, encouragement, and positive opinion of a farm, its structure, and development can strongly influence the potential successor's decision to take over the farm and continue farming, and thus preserve continuity between generations and consequently enable the farm's further development and existence.

KEY WORDS: geography, farming, succession, mountain farms, perception, Slovenia.

The article was submitted for publication on March 17, 2010.

\section{ADDRESS:}

Boštjan »Kefo« Kerbler, Ph. D.

Urban Planning Institute of the Republic of Slovenia

Trnovski pristan 2, SI - 1000 Ljubljana, Slovenia

E-mail: bostjan.kerbler@uirs.si

\section{Contents}

$1 \quad$ Introduction $\quad 37$

2 Methods 37

2.1 Selecting factors and defining the terminology 37

2.2 Research sample and data sources 38

2.3 Work methods 38

3 Results and discussion 39

3.1 Owners' perception of the farm's distance 40

3.2 Owners' opinion regarding taking over the farm again 41

3.3 Owners' perception of farm size 42

Owners' opinion about the viability
of forest potential

3.5 Owners' opinion about the farm's financial capacity and encumbrance 44

3.6 Owners' opinion about future changes in the amount of work performed on the farm and its future size, and the future increase in income from the farm's resources $\quad 45$

4 Conclusion 46

5 References 47 


\section{Introduction}

Farmers are the only segment of society that must ensure their own preservation. On farms, management and ownership are transferred from one family generation to the next (Gasson and Errington 1993). David Laband and Bernard Lentz (1983) believe that succession on farms is five times as frequent as in other professions and provides the best example of transferring physical and human capital from one generation to the next. The transfer of human capital involves the transfer of general farming skills such as operating agricultural machinery, and specific knowledge typical of each individual farm. According to the same authors, the transfer of human capital between various generations within the same family also results in its enhancement; at the same time, this also increases the value of the physical capital (i.e., both its actual value and the awareness of its value). The authors emphasize that »when the majority of young people are only beginning to train for a profession, children on farms, especially those appointed or anticipated as farm successors, have already mastered a number of skills required to work on and manage the farm « (Laband and Lentz 1983, 311). During socialization, the potential successor to the farm obtains detailed insight into the work of the owner and the rural lifestyle in general, gains direct experience and knowledge transferred from previous generations, and also develops respect for all of this, especially land as the primary source of survival on the farm.

Due to the succession characteristics described above, one can assume that parents' orientation plays an extremely important role in preserving continuity between generations on farms. In a traditional and largely patriarchal society such as an agrarian society, the orientation of farm owners (i.e., their viewpoints, perceptions, and thoughts) is even more important. According to Hendrik Tietje (2004; cited in Neldert et al. 1981), parents' orientation is often passed onto children. It can be concluded that in Slovenia this is especially true for farms in hilly regions, which, unlike the valleys and flatland areas, have for centuries been characterized by specific development that was based on the farms' self-sufficiency and isolation of agrarian society. According to Franc Hribernik $(1993,254)$, »the same social system is reproduced especially if the traditional agrarian society is poorly socially differentiated from the inside and if the present and future are dominated by a patina of the past, which continues to be reproduced in the process of socialization, and the agrarian culture is passed directly from one generation to the next. "The purpose of this paper is to prove this hypothesis and - if it is shown to be true - to establish the importance of owners' perceptions and opinions on the existence and future development of Slovenian mountain farms.

Perception is a psychological process, in which individuals interpret information from the environment and form their own ideas about the world based on this information. Because perceptions usually differ significantly from objective reality and have a strong influence on people's behavior, behavior is not based on reality itself but rather on the perception of what reality truly is (Treven 1998). The idea of the presumed connection between owners' perceptions and continuity between generations proceeds from a study conducted as part of the doctoral program (cf. Kerbler 2007), whose findings were presented in the paper titled $»$ The Influence of Factors of the Socio-Geographical Structure of Mountain Farms in Slovenia upon Farm Succession Statuses and Decisions « (cf. Kerbler 2008). This study established which factors connected with a farm's socio-geographical structure influence the farm's succession. During the talks that followed this study, its results were presented to the general public, especially farmers and agricultural advisers. This gave rise to considerable discussion, in which the factors reflecting the owners' perceptions and opinions about the structure of their farms stood out among those relevant to farm succession. It started becoming apparent that these factors played a much greater role in farm succession than had been presumed at the end of the study, and that their importance was even greater than that of other factors. Based on the overview of international and Slovenian literature, it was established that the relationship between these and other factors that are supposed to have an impact on succession had not been studied yet. Therefore, the hypothesis and findings presented in this paper are unique.

\section{Methods}

\subsection{Selecting the factors and defining the terminology}

The role of owners' perceptions and opinions in preserving the continuity between generations on Slovenian mountain farms was established based on the impact of the following factors:

- Owners' perceptions of the farm's distance;

- Owners' opinion on whether they would still choose to take over and run the farm if they had to decide again; 
- Owners' opinion about future changes in the amount of work performed on the farm;

- Owners' perception of farm size;

- Owners' expected future changes in farm size;

- Owners' opinion about the viability of forest potential;

- Owners' opinion on whether income from the farm's resources would increase the most in the future;

- Owners' opinion about the farm's financial capacity for investing in further development;

- Owners' opinion about the farm's encumbrance on future development due to loans and other financial burdens.

Factors were selected from the total of 45 factors included in the study; these were factors connected with the settlement, property, demographic, production (economic), technical, development, and innovative structure of individual farms (cf. Kerbler 2007). How they influence farm succession status and decisions connected with farm takeovers and transfers was examined. The first term refers to whether a person has already been or will be appointed successor to the farm and will assume full managerial control of the farm from the owner with certainty, thus also becoming the new owner of the farm. The second terms refers to whether this person has already decided to succeed the owner and also continue farming after taking over the farm.

\subsection{Research sample and data sources}

In order to make the findings as relevant and farm structure as homogeneous as possible, a target group of mountain farms was formed to determine the effects. The farms had to resemble one another as much as possible and were selected using the following criteria:

- They had to be located in alpine or prealpine Slovenian regions.

- Their production had to focus on livestock breeding.

- The owners had to be at least 45 years old.

The last criterion was selected because the issues of farm succession only become relevant to owners' plans when they are 45 years old. At that time, their anticipated successors (if these are their children) are old enough to form their own opinion about the owner's plans and anticipations regarding the farm's succession and also make decisions in this regard. Clive Potter and Matt Lobley (1992) found that the majority of young owners expect succession to take place on their farms regardless of whether there are realistic bases for this. At the same time, Potter and Lobley (1996a) also report that the majority of owners under 45 believe that it is too early to talk about farm succession and plans connected with this. According to Christoph R. Weiss (1999), Ayal Kimhi and Ray Bollman (1999), and Luka Juvančič (2002), the probability of abandoning the farm decreases until age 43 to 45 , and after this it begins increasing steadily. Weiss (1999) links this with the lifecycle effect. These findings confirm that the decision to only include owners 45 years or older in the research sample was correct.

Because statistical services do not provide all of the data required for this study, they were obtained by conducting surveys. The final research sample used to determine the effects of the selected factors thus included 789 or $11.6 \%$ of all mountain farms, which were defined as the target group on the basis of the criteria used. Despite this low percentage, the research sample is still representative; this can be established by comparing certain basic characteristics of the sample with the data that apply to all the mountain farms within the target group (i.e., data obtained during the 2000 farm census). On average, the owners of the mountain farms included in the sample were 60.9 years old, whereas the average age of all owners in the target group was 60.4. In both cases, three-quarters were male owners. Differences were also small in terms of average farm size: the average farm size in the research sample was $21.7 \mathrm{ha}$, and the average size of all farms in the target group was 20.6 ha. Therefore, the research was continued by generalizing these results to all the mountain farms in Slovenia that meet the target group's criteria.

\subsection{Work methods}

The assumed connection between owners' perceptions and continuity between generations as well as the strength of these connections was determined using special regression models, also known as discrete choice models; this term was borrowed from William Greene (2003), who also refers to these models as qualitative response (QR) models. In contrast to traditional linear regression models (cited in Gujarati 1995), 
the selected models provide insight into the causal relationships between the explained dependent variable $\left(Y_{i}\right)$ and one or more explanatory independent variables $\left(X_{1} \ldots X_{k}\right)$, even though the continuous quantitative values of the dependent variable are unknown and only the final number of outcomes with discrete qualitative values are isolated (Bajt and Štiblar 2002; Maddala 1999; Wooldridge 2002). John Fox (1997) reported that regression models are characterized by the fact that the value of the dependent variable can be forecast based on the model selected and the assessment of its parameters using the values of explanatory variables; in contrast, discrete choice models - as probability models - make it possible to forecast the probability of response and choice, or the probability of the events' occurrence (Liao 1994; Wooldridge 2002). Greene (2003) explains this with the following equation:

Prob $($ event $j$ has occurred $)=\operatorname{Prob}(Y=j)=P$ [relevant effects, parameters $]$,

in which Prob $(Y=j)$ denotes the probability that event $j$ occurs under circumstances $X_{i}$ and »event « denotes an individual's choice among the alternatives or outcomes of dependent variable $Y_{i}$.

This study was limited to two outcomes of dependent variable $Y_{i}$. These were events connected with farm takeovers and further farming activity on these farms:

$Y_{i}=1$ The farm will be taken over by a successor that will continue to engage in farming.

$Y_{i}=0$ No succession will occur on the farm, or the farm will be taken over by a successor that will not engage in farming.

One of the two outcomes of dependent variable $Y_{i}$ corresponded to each of the 789 farms included in the research sample: $Y_{i}=1$ corresponded to 481 farms or $60.9 \%$ of all the sample farms, and $Y_{i}=0$ corresponded to 308 farms or $39.1 \%$ of all farms. The algorithm used to distribute the farms within the group is described in greater detail in a previous paper by the author (cf. Kerbler 2008a).

Because dependent variable $Y_{i}$ has two outcomes, there was a choice among two methodological approaches - the binary choice logit and probit models - to apply a discrete choice model or assess the effects of the selected factors as explanatory variables on dependent variable Yi. According to Damodar Gujarati (1995), the final choice depends primarily on the computer software that is available to the researcher for analysis. Gangadharrao Soundalyarao Maddala (1999) claims that, assuming that the research sample is sufficiently large, the results of both methodological approaches to binary choice models do not differ significantly. Based on this, it was decided to use the binary choice probit model, also known as the normit model. Because the dependent variable has two outcomes in this case, this involves a binary choice probit model. The model was developed using LIMDEP 7.0 software, which was specially produced for calculating linear and non-linear regression models.

\section{Results and discussion}

The results of the empirical analysis showed that the factors reflecting owners' perceptions and opinions are extremely important in terms of the succession status and decisions on mountain farms. Compared to other factors included in the study (cf. Kerbler 2008b), the strength of the selected factors is extremely great in nearly all the examples (Table 1).

Table 1: Strength of calculated effects of factors reflecting owners' perceptions and opinions.

\begin{tabular}{lc}
\hline Factors reflecting owners' perceptions and opinions & Strength of effect \\
\hline Owners' perception of the farm's distance & Very great \\
Owners' opinion about whether they would still choose to take over and run the farm if they had to decide again & Very great \\
Owners' opinion about future changes in the amount of work performed on the farm & Very great \\
Owners' perception of farm size & Moderate \\
Owners' expected future changes in farm size & Very great \\
Owners' opinion about the viability of forest potential & Great \\
Owners' opinion about whether income from the farm's resources would increase the most in the future & Very great \\
Owners' opinion about the farm's financial capacity for investing in further development & Very great \\
Owners' opinion about the farm's encumbrance on future development due to loans and other financial burdens & Very great \\
\hline
\end{tabular}

Note: The strength of the effect of individual factors is determined using the $t$-value of the calculated correlations. 
The significance of the factors selected is even more obvious if the $t$-value is divided into classes and converted into a 5 -point scale $(1=$ no effect, and $5=$ very great effect $)$, and then the average effect strength is calculated. The average strength of effects reflecting the owners' perceptions and opinions is 4.66 , and the average value for other factors is 3.05 .

\subsection{Owners' perception of the farm's distance}

The results of the empirical analysis showed that the farm's location generally has an important effect on the succession status and decisions on the farm; however, for the succession itself, the way the owner perceives the farm's distance is more important than the physical or actual (temporal or spatial) distance of the farm from the municipal center, primary school, store with basic commodities, physician, veterinarian, and closest main road in the valley.

The effect of this factor is negative, which means that on farms whose owners believe they are remote or far from the closest administrative centers and the main road in the valley the probability that the farm will be taken over by a successor that plans to continue farming is $40 \%$ lower than on farms whose owners believe otherwise. On $60.3 \%$ of the farms whose owners consider them remote, isolated, and far from the closest administrative centers and the main road in the valley, no succession will take place or the farms will be taken over by successors that do not plan to continue farming. In contrast, takeovers and continued farming will take place on $79.6 \%$ of the farms that are not perceived as remote and isolated by their owners.

Following the Second World War, the increase in car ownership and improved roads in hilly regions resulted in a gradual decrease in the actual temporal and spatial distance of farms. However, if owners still perceive their farms as remote, reduced physical distance does not have any relevant effect on more frequent farm takeovers. This was also confirmed by a thorough analysis of the information collected in the survey, for which farms 5 to $15 \mathrm{~km}$ from the municipal center were selected; this means that two-thirds of the farms studied were included in the survey. Nearly $50 \%$ of the farm owners perceive their farms as

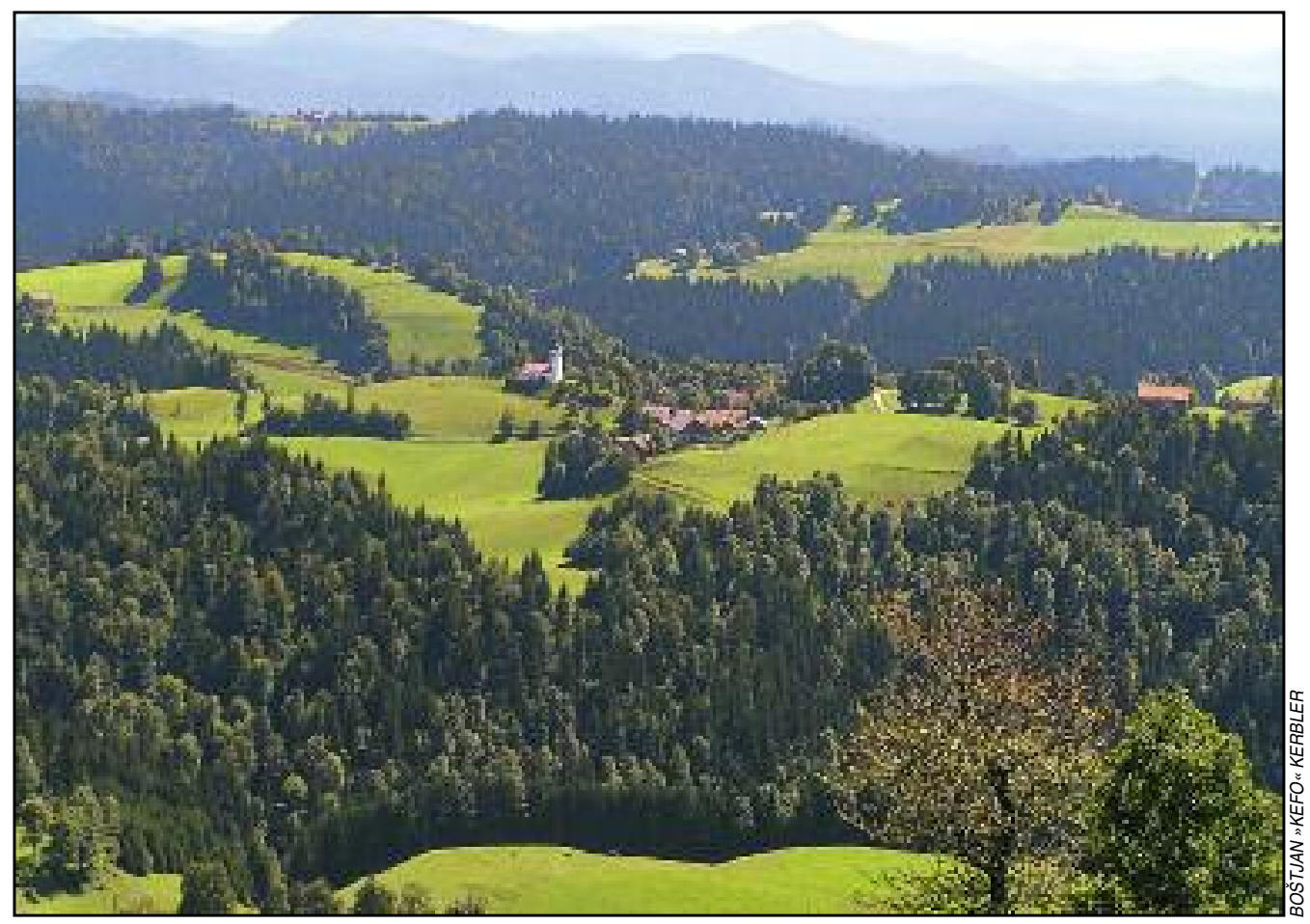

Figure 1: On mountain farms, succession is more likely to occur if their owners believe they are not remote or isolated. 
remote. It turned out that in most cases their opinion in particular affects the farm succession status and decisions because the average farm distance was the same in both groups. On farms whose owners perceive them as remote, succession and continuation of farming activity will thus take place in only $41 \%$ of cases; in contrast, among the farms whose owners do not perceive them as remote, this percentage is twice as high $(82.2 \%)$. Based on these findings, it is possible to further improve Hribernik's (1996) idea that on farms far from the main transport and social communications there is a very low probability that any children that have moved away will return to the farm. It is believed that the probability of succession on these farms would be greater if their owners believed they were not remote or isolated.

\subsection{Owners' opinion regarding taking over the farm again}

According to Ferdinand Fasterding $(1995,1999)$ and Tietje (2004), owners' conviction that they would take over and run the farm again if they had the opportunity shows that they are satisfied with their occupation. In addition, it also reflects their pleasure in working and living on the farm, and their respectful attitude towards the farm and preserving the heritage of previous generations. All of this has a very important motivational effect on the appointed or anticipated successor's preparations and decisions to take over the farm; this is also confirmed by the results of the empirical analysis. Among the farms whose owners would still decide to take over and run them, $77.8 \%$ will be taken over by successors that will continue farming; on $66.8 \%$ of farms whose owners would not decide to take over and run them again, no succession will take place or they will be taken over by successors that do not plan to engage in farming. Another interesting finding is that on nearly $84 \%$ of the farms on which successors are not yet precisely known or no one is planned for this role and whose owners would not decide again to take over the farm, the owners will not seek successors, which means the continuity between generations will not be preserved.

The importance of satisfaction with farm work is also reflected in the opinion of a young owner of a mountain farm that will continue farming there. He is 24 years old, graduated from an agricultural sec-

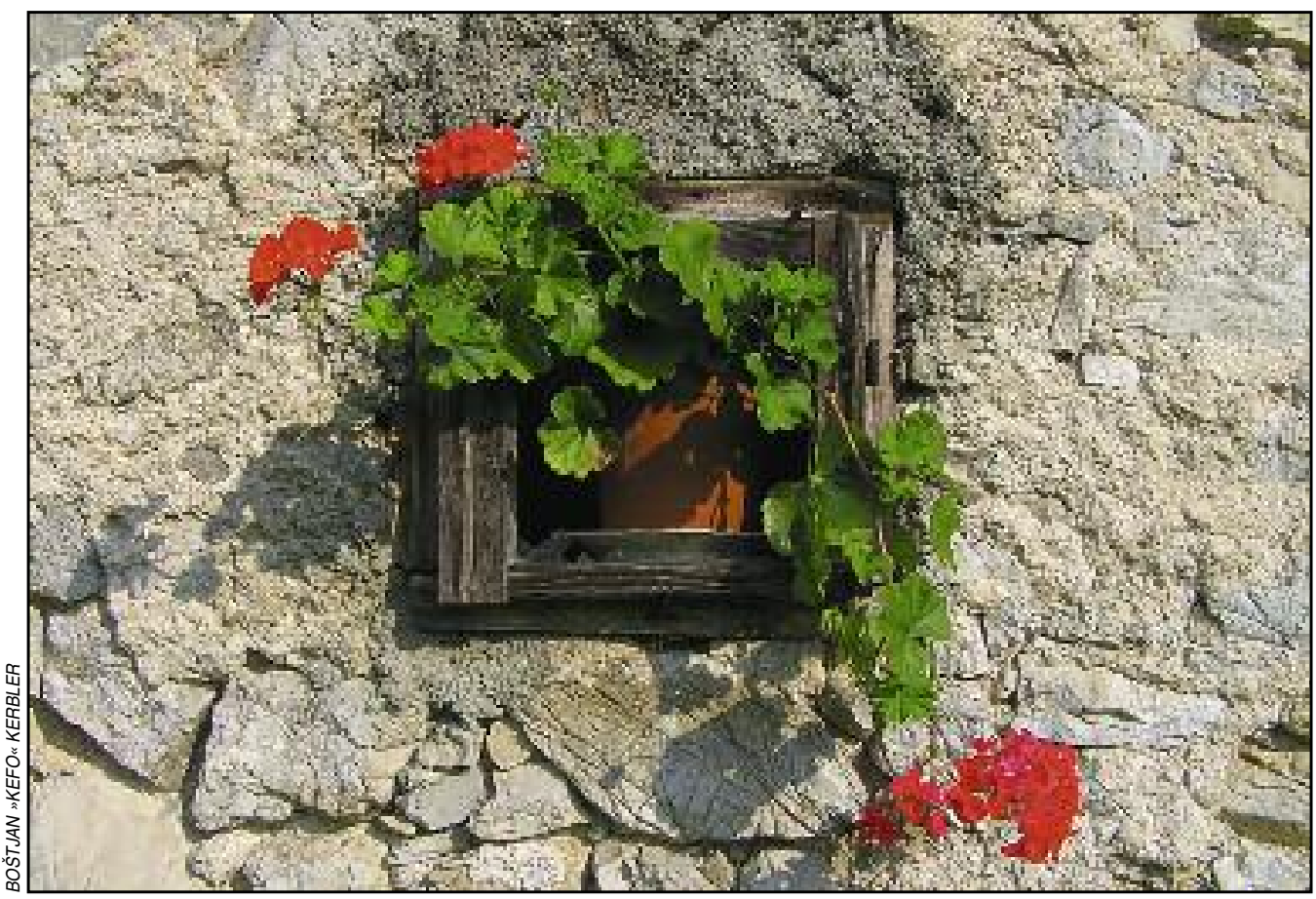

Figure 2: Owners' pleasure in working and living on the farm has an important motivational effect on the appointed or anticipated successor's decisions to take over the farm. 
ondary school, wishes to increase the livestock on the farm in the future, and plans to furnish the farm with new machinery and other equipment. The previous owner, his father, would immediately choose to take over and run the farm again if he had this opportunity. The young owner wrote the following comment in the survey: »People have really enjoyed working on this farm and kept at it for quite a few years now. That's why I decided to keep on farming when I was little. We farm all the land, the steepest hills too. If things don't get too hard for the farmers, I'll be happy to keep working on the farm. But I don't like it when they keep a close eye on the farmers and I don't want to turn into a slave."

In contrast, the following example shows how the owner's dissatisfaction with his occupation can have exactly the opposite effect. The owner wrote the following: »I wouldn't want any of my kids or grandkids to work so hard and lead such a deprived life. Just loving nature and animals can't make up for all the sacrifices and hard work on a mountain farm like this."

On this farm, a successor has not been appointed yet and no one is planned for the position. The owner is not even looking for one and is convinced that he will not find and appoint one by the time he stops running the farm. If he had the opportunity, he would not decide to take over and run the farm ever again.

\subsection{Owners' perception of farm size}

Researchers that studied the influence of factors on farm succession - for example, Kimhi and Ramon Lopez (1999) in Maryland, Alfred Stiglbauer and Weiss (2000) in Upper Austria, and Kimhi and Noga Nachlieli (2001) in Israel - usually included farm size in their empirical analyses of succession, which points to the great importance of this factor for succession. Thomas Glauben et al. (2003) report that the size of German farms in the 1990s was even the main factor in farmers' decisions to stop farming. According to Thia Hennessy (2004), farm size is even more important for determining influences on the farm succession status and decisions than the farm's income. Hennessy believes that income is merely a reflection of the farm's current capacity, rather than future technical and economic capacity. These findings match

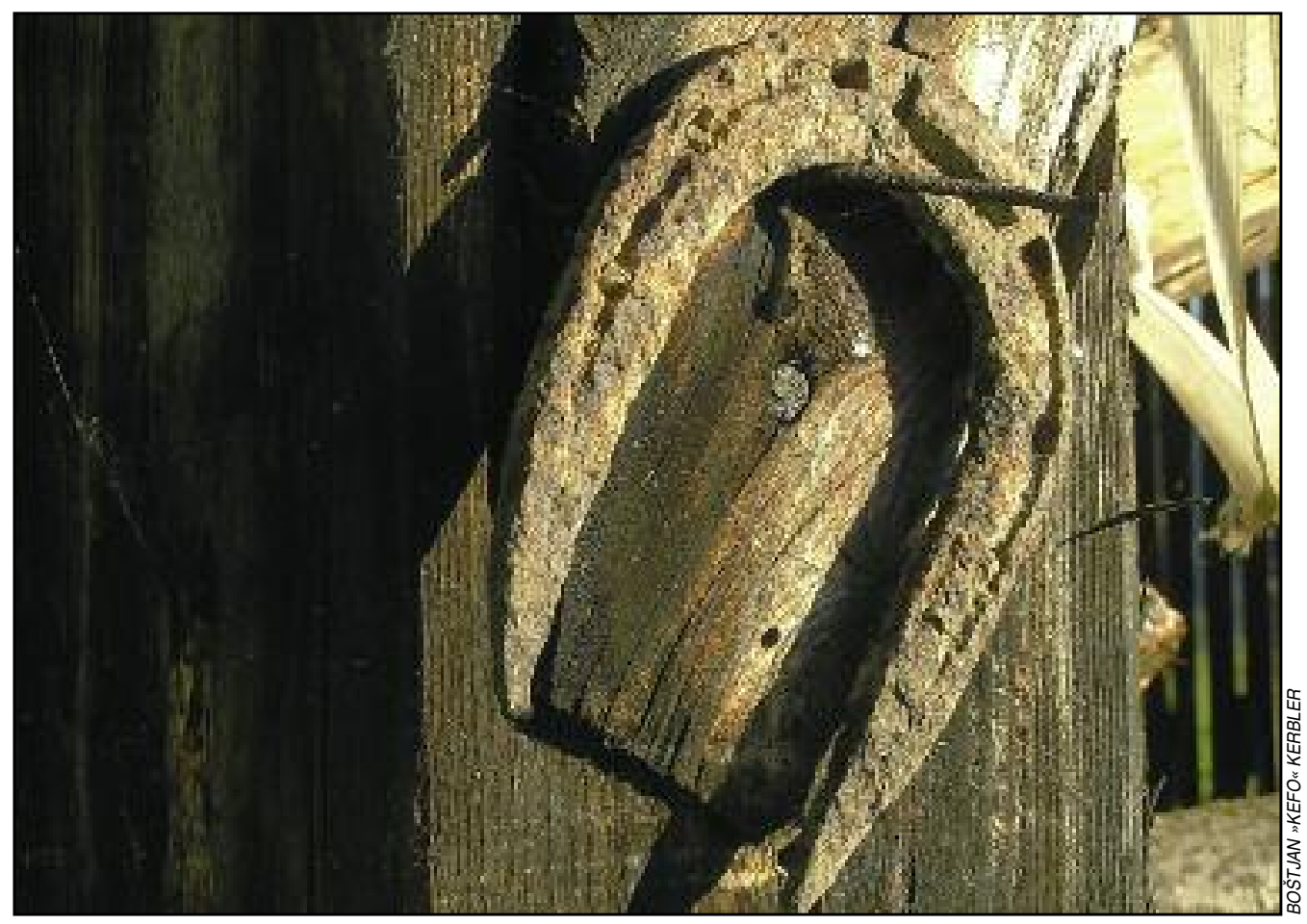

Figure 3: Owners' perception of farm size is more important to the farm succession status and decisions than quantified farm size. 
those established by Rosemary Fennell (1981) and Ruth Gasson et al. (1988), who claim that insufficient farm size is one of the main reasons why owners' children do not take over farms. This is also confirmed by Hribernik $(1996,16)$, who reports that "farms with only a few hectares of land cannot provide a comparable income to workers and their dependents in a farming household « (especially if these farms are in areas with unfavorable farming conditions) »and subsequently the kind of social security level that would encourage young people to maintain farms as production and property units. If farms are too small, the potential successors and other members of the owner's household and other households on the farm find employment outside the farm.«

The importance of farm size for farm succession has also been confirmed by this study. Irrespective of which factor was used to express farm size (e.g., the area of farmland used or livestock units), the probability of farm takeover and continued farming increased with an increase in farm size.

In addition to quantified farm size, it was assumed that owners' perception of farm size was also important to the farm succession status and decisions, which had not been studied yet. The results of this empirical analysis confirmed the hypothesis. The probability that a farm will be taken over by a successor that plans to continue farming increases by $26 \%$ if the owners believe that the farm is large. A more detailed analysis also shows that, on the one hand, succession and further farming will take place on nearly $25 \%$ of farms that are smaller than the average farm studied, but whose owners nonetheless believe they are large, and, on the other hand, that this will not occur in nearly $10 \%$ of the farms that are larger than the average farm studied, but whose owners believe they are small.

\subsection{Owners' opinion about the viability of forest potential}

Milan Natek (1992) establishes that in addition to livestock breeding forestry is the most important economic industry for ensuring further development of mountain farms. According to him, »many mountain farms would have never made such progress if their farming activities had not been supported by forests

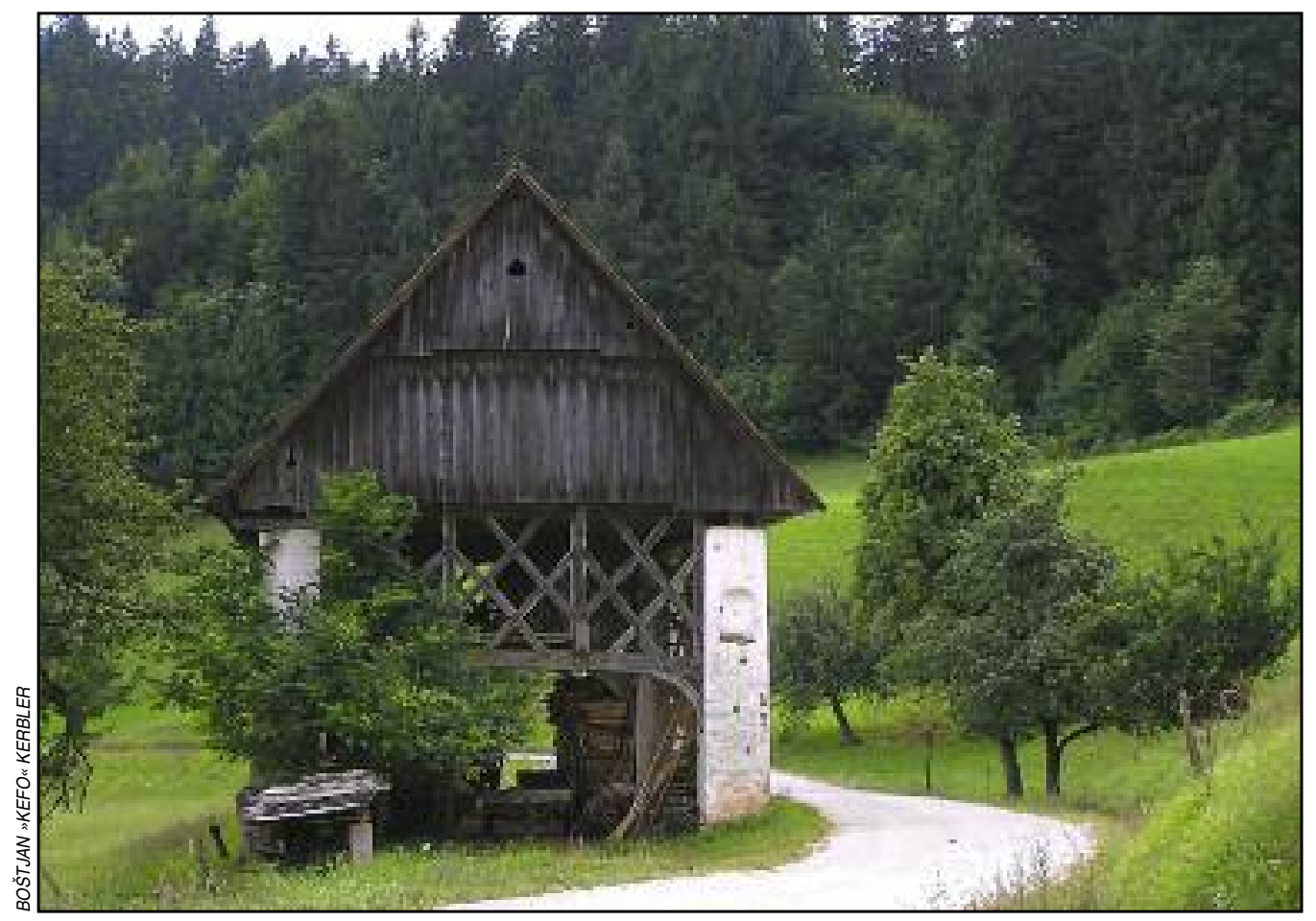

Figure 4: Mountain farms without viable forest potential often cannot ensure continuity between generations. 
with large supplies of wood « (Natek 1983,251). This is also confirmed by Lojze Čampa (1992), who believes that from the beginning of its commercialization (i.e., in the nineteenth century), forest wood has been capital well invested or a reserve in times of economic crises, farming failures and accidents, inheritance payouts, or debts. During a general or farming crisis, wood sales can also replenish the income deficit in agricultural (livestock breeding) production. Based on this, it was assumed that forestry had an important influence on the farm succession status and decisions.

However, as established by Tone Robič et al. (1986), forests owned by mountain farms have been significantly felled due to the farms' great financial needs: »Since the Second World War, farms have been using their forest proceeds to finance the construction of a road network, which is a prerequisite for more intensive farming, and indirectly also to modernize and convert the farms « (18). With regard to decisions concerning taking over the farm, the viability of forest potential is a more important indicator than the area of forest land or the annual cut. The viability of forest potential is a qualitative factor involving an assessment or opinion about whether the farm's forest has already been greatly felled. A farm can still have a significant annual cut, even though the forest has already been severely felled; however, when the upper (permitted) limit is reached, the annual cut can decrease dramatically. Forests are renewable sources, but their regeneration takes a long time, and thus in the event of frequent and unpredictable economic fluctuations the survival of mountain farms is also threatened. The factor »viability of forest potential« has been developed precisely for this study and is thus used for the first time in studying the influences of factors on farm succession.

The results of the empirical analysis confirmed the hypothesis. On farms whose owners believe their forest has already been drastically reduced, the probability that they will be taken over by successors that will also continue farming there is $38.4 \%$ lower than on farms whose owners believe their forest potential is still viable. More than two-thirds of farms without any viable forest potential cannot ensure continuity between generations, whereas nearly three-quarters of farms with viable forest potential can. A more detailed analysis showed that on the majority of farms whose forests have already been greatly felled the owners have already appointed their successors or have someone in mind, but these have not yet decided to take over the farm; in addition, the owners are very pessimistic about this and believe the takeover will definitely not happen. It is also interesting that viable forest potential is characteristic of nearly $82 \%$ of the farms on which successors have not yet been appointed or planned, but whose owners are optimistic and believe that their farms will definitely retain the continuity between generations and that their successors will continue farming after taking over the farm.

\subsection{Owners' opinion about the farm's financial capacity and encumbrance}

The factor reflecting the owner's opinion about the farm's financial capacity for investing in further development and the factor expressing the opinion about the farm's encumbrance for further development due to loans and other financial burdens are extremely important with regard to the potential successors' decisions to take over the farm. The findings on the influences of the first factor match the results of studies by Glauben et al. (2004), and the findings regarding the influences of the second factor match the findings by Glauben et al. (2002), Minna Väre and Weiss (2003), and Väre et al. (2006). If the owners believe their farms are financially capable of investing in further development, the probability that they will be succeeded by a successor that will also continue farming is $38.6 \%$ higher than if they believe the farms are not financially capable. The probability that the continuity between generations will be preserved is also lower if the owners believe that their debts due to loans or other financial burdens constitute too great an encumbrance for the farm to develop further.

It is especially important that on nearly three-quarters of the farms whose owners believe they do not have sufficient capital to invest in further development successors have not only already been appointed, but have also already decided to take over the farm and continue farming there. On the other hand, on more than $45 \%$ of the farms whose owners believe that financial burdens endanger the farm's further development, successors have not yet been appointed or are not anticipated yet and their owners also see no prospects of securing one. Twenty percent of owners on farms with financial burdens have already appointed their successors or have one in mind, but these have decided not to take over the farms or will not continue farming there after the takeover. 


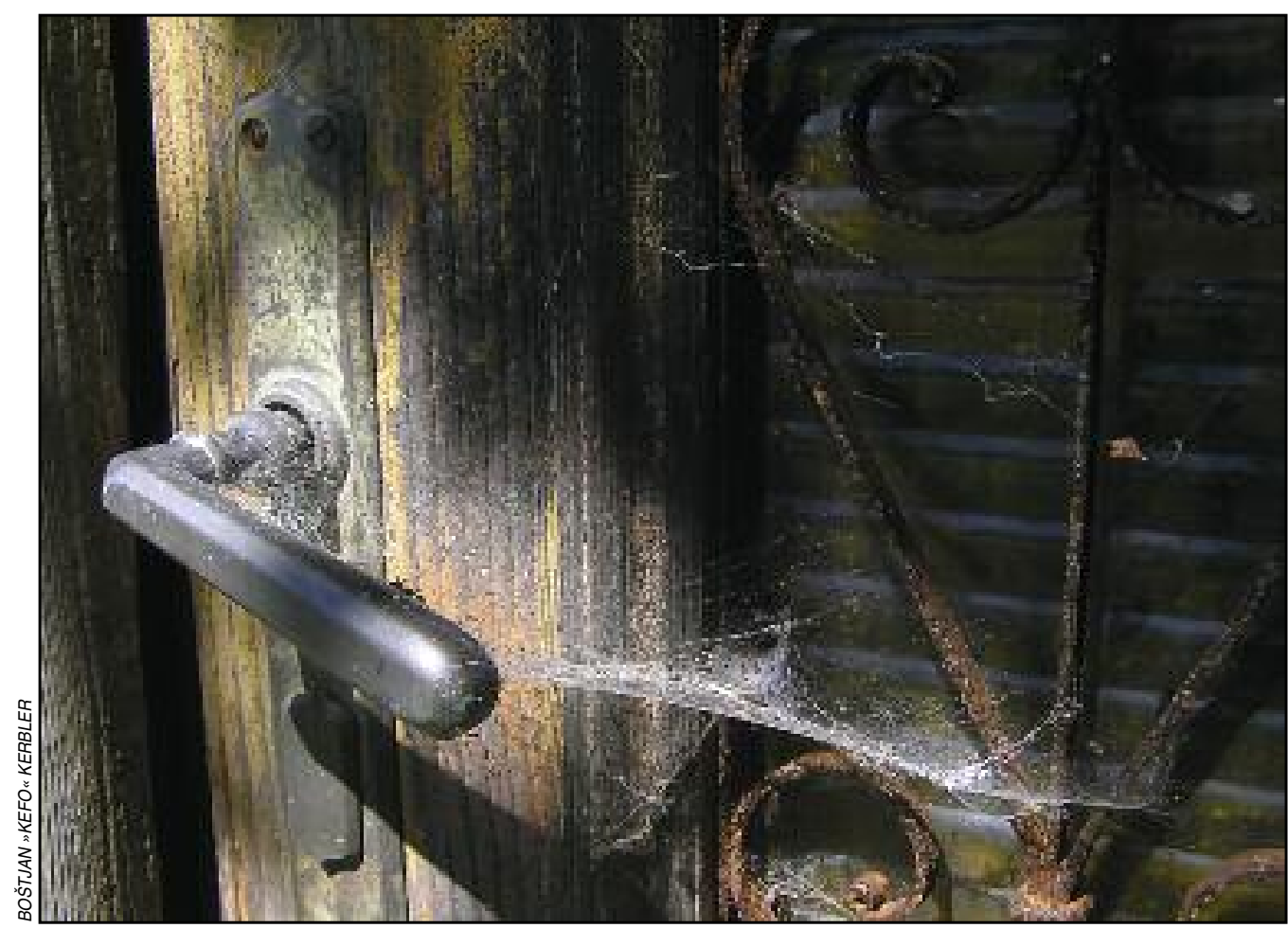

Figure 5: If owners are concerned about their farms' further development or do not have faith in their farms as their primary sources of income, the probability that these farms will be taken over and their successors will continue farming there is considerably lower than if the owners think more positively.

If the owners are not sure about their farm's capital power and consequently their future development and if they are concerned about the farms' future development due to financial burdens, this doubt is therefore an important piece of information for the potential successors that are deciding on their future profession. Ana Barbič $(1993,265)$ also establishes that »young people that choose to continue farming do this increasingly more for economic and increasingly less for emotional reasons. «It is more than obvious that young people - in contrast to their parents - see their farms as capital that must be constantly increased, rather than as a way and purpose of life or a life project (Kerbler 2003).

According to Matija Kovačič (1995), the increasingly aggravated farming conditions demand continuous introduction of innovations and adjustment of production structure to market demands. In such circumstances, only farms whose owners are sufficiently self-confident, creative, and flexible, and who have self-initiative and keep abreast of the latest innovations, achieve positive development. All of these properties are usually typical of young people - that is, the potential successors. Therefore if young people, who usually possess these characteristics, learn from their parents that their farm is not financially suitable for investment in future development, they usually do not decide to take over the farm (as shown by the results of the empirical analysis).

\subsection{Owners' opinion about future changes in the amount of work performed on the farm and its future size, and the future increase in income from the farm's resources}

The influences of these factors must be interpreted with caution. Specifically, the anticipated changes in the extent of work performed on the farm and its size, and the increase in income from the farm's resources 
can determine the succession status and decisions and their consequences. For example, Potter and Lobley (1992) interpreted the use of farmland as a consequence of farm succession status and decisions, but not its causes. According to them, the succession status and expectations should have a significant long-term effect on determining the farm's course of development as well as the owners' behavior and decisions (Potter and Lobley 1996b). In various articles (1992, 1996a, 1996b), they discuss the influences of the following three factors:

1. Succession;

2. Successor;

3. Retirement.

The first two factors are taken into account if a successor has already been appointed or is planned on the farm, and the third if the successor has not yet been appointed or no one is anticipated for this position.

1. The succession effect is reflected in the fact that the anticipation that succession will occur motivates the owners to make systematic investments in their farms' development. This influence is the greatest on farms for which succession is carefully planned and usually already begins with the birth of the owner's first child and strengthens when the successor himself decides to take over the farm.

2. When the appointed or anticipated successors take over part of the farm's management, one can talk about the successor effect or new blood effect. Young successors are extremely innovative at the beginning of their careers, which is why Michele Blanc and Philippe Perrier-Cornet (1993) believe that they are the main drivers behind the modernization of agricultural structures.

3. The retirement effect is connected with the owner's retirement. On farms without any successors, the number of man-hours, area of farmland used, and volume of agricultural production gradually decrease after the owner's retirement; in addition, machinery and other equipment are increasingly poorly maintained as well as buildings, which are often empty. Weiss (1999) and Stiglbauer and Weiss (2000) cite Zvi Griliches and Haim Regev (1995), who claim that this phenomenon is typical of »doomed firms, « which in this way show their awareness that their end is approaching.

Potter and Lobley (1992) statistically confirmed that the owner's retirement as well as expected succession and the presence of a successor on the farm influence the farm's structure, but in their study they emphasized several times that the distinction between the cause and effect is not clear. Stiglbauer and Weiss (2000), Kimhi and Nachlieli (2001), and Glauben et al. (2004) dealt with the same dilemma regarding cause-and-effect relations. They suggested a broader observation timeframe in order to understand the causes and effects, in which research should focus on exploring the lifecycle of every individual farm. Because such research would have had completely different goals and would have also demanded different research methods and techniques, any attempt to verify whether the definition of each factor as the cause of the succession status and decisions was justified would have far exceeded the context of this study. Therefore, this research followed the example of the majority of studies dealing with succession probability, and defined the succession status and decisions as the effect of various factors or, in this case, the owner's opinion about future changes in the extent of work performed on the farm and its size, and the future increase of income from farm resources.

Irrespective of which explanatory variable was included in the empirical analysis (i.e., the opinion about the extent of the work performed and farm size, or the opinion about the income originating from the farm's own resources), it turned out that its anticipated decrease had a strong negative influence on the succession status and decisions on mountain farms, and that its increase had a strong positive influence. The probability of taking over the farm decreases the most if the owners believe that the size of their farms will decrease in the future (i.e., by $58.3 \%$ if the size is expressed by the share of farmland used, or by $62 \%$ if the size is expressed by the number of livestock units). Succession will not take place on only $12.6 \%$ of farms whose owners anticipate an increase in livestock production.

\section{Conclusion}

The results and discussion confirm the hypothesis that on Slovenian mountain farms the owner's perception and opinions play a very important role in ensuring continuity between generations. The behavioral patterns and mindsets that the potential successors obtain during socialization from their par- 
ents, especially the owner, who sets an example for the potential successor in terms of his future occupation, are preserved extremely well in the transfer of farming from one generation to the next. It was established that with their positive attitude, encouragement, satisfaction, love for farm work and farm life, and a positive opinion about the farm, its structure, and its current and future development, owners can have an important influence on the decisions of potential successors to take over the farm and also continue farming there, thus preserving continuity between generations and ensuring the farm's further development and survival. Therefore, in addition to financial incentives as measures to promote farm takeovers, especially in Slovenia's mountainous regions, the government should also disseminate these new findings among the farming population: that the owners themselves can contribute greatly to farm takeovers. It is not enough to merely encourage the potential successor to become the future owner of the farm; owners must also believe in what they are training their successors for.

\section{References}

Bajt, A., Štiblar, F. 2002: Statistika za družboslovce. Ljubljana.

Barbič, A. 1993: (Samo)obnavljanje kmečkega sloja v Sloveniji. Sodobno kmetijstvo 26-6. Ljubljana.

Blanc, M., Perrier-Cornet, P. 1993: Farm Transfer and Farm Entry in the European community. Sociologia

Ruralis, 33-3-4. Oxford. DOI: 10.1111/j.1467-9523.1993.tb00967.x

Čampa, L. 1992: Gozd in njegove funkcije v razvoju podeželja. Ljubljana.

Fasterding, F. 1995: Hofnachfolge in Westdeutschland. Landbauforschung Völkenrode 45-1. Braunschweig. Fasterding, F. 1999: Nachfolge in landwirtschaftlichen Betrieben in Deutschland. Berichte über Landwirtschaft 77-2. Berlin.

Fennell, R. 1981: Farm Succession in the European Community. Sociologia Ruralis 21-1. Oxford. DOI: 10.1111/j.1467-9523.1981.tb00290.x

Fox, J. 1997: Applied regression analysis, liner models, and related methods. London, New Delhi.

Gasson, R., Crow, G., Errington, A., Hutson, J., Marsden, T., Winter, D. M. 1988: The Farm as a Family Business: A Review. Journal of Agricultural Economics 39-1. Oxford.

Gasson, R., Errington, A. 1993: The Farm Family Business. Wallingford.

Glauben, T., Tietje, H., Weiss, C. H. 2002: Intergenerational Succession on Farmily Farms: Evidence from Survey Data. Internet: http://www.food-econ.uni-kiel.de/Workingpaper/Ewp0202.pdf (17.2. 2010).

Glauben, T., Tietje, H., Weiss, C.H. 2003: Agriculture on the Move: Exploring Regional Differences in Farm Exit Rates. Internet: http://www.food econ.uni kiel.de/Workingpaper/Fe0308.pdf (9. 12.2003).

Glauben, T., Tietje, H., Weiss, C. H. 2004: Succession in Agriculture: A Probit and Competing Risk Analysis. Internet: http://www.food econ.uni kiel.de/Workingpaper/FE0406.pdf (17.2.2010).

Greene, W. H. 2003: Econometric analysis. Prentice Hall.

Gujarati, D. N. 1995: Basic econometrics. New York.

Hennessy, T. 2004: Examining the Factors that Affect Intergenerational Transfer in Irish Farming: An Application of Limited Dependent Variable Models. Osebni vir (8. 4.2004).

Hribernik, F. 1993: Vpliv vrednotenja izobraževanja in vrednotenja poklicev na šolanje kmečke mladine. Sodobno kmetijstvo 26-6. Ljubljana.

Hribernik, F. 1996: Ali lahko kmetije v Sloveniji zagotavljajo primerno socialno varnost kmečkemu prebivalstvu? Socialno delo 35-1. Ljubljana.

Juvančič, L. 2002: Model odločanja o zaposlovanju na kmečkih gospodarstvih v Sloveniji. Doktorska disertacija, Biotehniška fakulteta Univerze v Ljubljani, Oddelek za zootehniko. Ljubljana

Kerbler, B. 2003: A conception of developmental typology of mountain farms: a case study of the municipality Ribnica na Pohorju. Acta geographica Slovenica 43-2. Ljubljana. DOI: 10.3986/AGS43203

Kerbler, B. 2007: Povezanost nasledstva na hribovskih kmetijah z njihovo socialnogeografsko strukturo. Doktorska disertacija, Filozofska fakulteta Univerze v Ljubljani. Ljubljana.

Kerbler, B. 2008a: Stanje nasledstva na hribovskih kmetijah v Sloveniji. Dela 30. Ljubljana.

Kerbler, B. 2008b: The influence of factors of the socio-geographical structure of mountain farms in Slovenia upon farm succession statuses and decisions. Acta geographica Slovenica 48-2. Ljubljana. DOI: 10.3986/AGS48203 
Kimhi, A., in Bollman, R. 1999: Family farm dynamics in Canada and Israel: the case of farm exits. Agricultural Economics 21-1. Oxford. DOI:10.1016/S0169-5150(99)00015-8

Kimhi, A., Lopez, R. 1999: A Note on Farmers' Retirement and Succession Considerations: Evidence from a Household Survey. Journal of Agricultural Economics 50-1. Oxford. DOI: 10.1111/j.1477-9552.1999.tb00802.x

Kimhi, A., Nachlieli, N. 2001: Intergenerational Succession on Israeli Family Farms. Journal of Agricultural Economics 52-2. Oxford. DOI: 10.1111/j.1477-9552.2001.tb00924.x

Kovačič, M. 1995: Funkcije kmetijstva v prihodnjem razvoju podeželja. Ljubljana.

Laband, D. N., Lentz, B. F. 1983: Occupational Inheritance in Agriculture. American Journal of Agricultural Economics 65-2. Oxford.

Liao, T. F. 1994: Interpreting probability models: logit, probit, and other generalized linear models. London, New Delhi.

Maddala, G. S. (1999): Limited dependet and qualitative variables in econometrics. Cambridge, New York, Melbourne.

Natek, M. 1983: Gospodarstvo hribovskih kmetij na vzhodnem delu Dobroveljske planote. Savinjski zbornik 5. Celje.

Natek, M. 1992: Prebivalstvo hribovskih kmetij na Pohorju. Geographica Slovenica 23. Ljubljana.

Potter, C., Lobley, M. 1992: Ageing and Succession on Family Farms: The Impact on Decision-making and Land Use. Sociologia Ruralis 32-2-3. Oxford. DOI: 10.1111/j.1467-9523.1992.tb00935.x

Potter, C., Lobley, M. 1996a: Unbroken Threads? Succession and its Effects on Family Farms in Britain. Sociologia Ruralis 36-3. Oxford. DOI: 10.1111/j.1467-9523.1996.tb00023.x

Potter, C., Lobley, M. 1996b: The Farm Family Life Cycle, Succession Paths and Environmental Change in Britain's Countryside. Journal of Agricultural Economics 47-2. Oxford. DOI: 10.1111/j.1477-9552.1996.tb00683.x

Robič, T., Anko, B., Cizej, D., Germek, V., Meze, D. 1988: Razvojni cilji kmetijsko nerazvitih območij. Ljubljana.

Stiglbauer, A. M., Weiss, C. R. 2000: Family and Non-family Succession in Upper-Austrian Farm Sector. Cahiers d'economie et sociologie rurales 54. Ivry.

Tietje, H. 2004: Hofnachfolge in Schleswig-Holstein. Doktorska disertacija, Institut für Ehnärungswirtschaft und Verbrauchslehre der Christian-Albrechts-Universität zu Kiel.

Treven, S. 1998: Management človeških virov. Ljubljana.

Väre, M., Weiss, C. H. 2003: Farmers' succession considerations and realization of succession plans. Internet: http://www.mm.helsinki.fi/čhsmakine/nova/Vare.pdf (24.2.2010).

Väre, M., Weiss, C. H., Pietola, K. 2006: Should one trust a farmer's succession plan? Empirical evidence on the intention behaviour discrepancy from Finland. Internet: http://ageconsearch.umn.edu/bitstream/24622/1/pp05va02.pdf (22.2.2010).

Weiss, C. R. 1999: Farm Growth and Survival: Econometric Evidence for Individual Farms in Upper Austria. American Journal of Agricultural Economics 81. Oxford.

Wooldridge, J. M. 2002: Econometric analysis of cross section and panel data. Cambridge, London. 



\title{
Vloga in pomen gospodarjevih dojemanj in mnenj za ohranjanje medgeneracijske kontinuitete na slovenskih hribovskih kmetijah
}

\author{
DOI: $10.3986 / A G S 50102$ \\ UDK: 911.3(497.4):631.111(23.01) \\ COBISS: 1.01
}

IZVLEČEK: Za družinske kmetije je značilno, da se medgeneracijsko prenašajo znotraj družine. S tem se na otroke prenaša tudi usmerjenost staršev, zlasti gospodarjev. Zaradi te značilnosti izhajamo v prispev$\mathrm{ku}$ iz domneve, da v Sloveniji na nasledstvo na kmetijah pomembno vplivajo prepričanja, mnenja in dojemanje gospodarjev. Izkazalo se je, da lahko gospodar s pozitivno naravnanostjo in spodbudami ter $\mathrm{z}$ dobrim mnenjem o kmetiji, njeni strukturi in njenem razvoju pomembno vpliva na to, da se potencialni naslednik odloči za prevzem kmetije in nadaljevanje kmetovanja ter ohrani medgeneracijsko kontinuiteto, s tem pa omogoči tudi nadaljnji razvoj in obstoj kmetije.

KLJUČNE BESEDE: geografija, kmetijstvo, nasledstvo, hribovske kmetije, percepcija, Slovenija

Uredništvo je prejelo prispevek 17. marca 2010.

NASLOV

dr. Boštjan Kerbler - Kefo

Urbanistični inštitut Republike Slovenije

Trnovski pristan 2, SI - 1000 Ljubljana, Slovenija

E-pošta: bostjan.kerbler@uirs.si

\section{Vsebina}

1 Uvod 51

2 Metode 51

2.1 Izbor dejavnikov in opredelitev terminov 51

2.2 Raziskovalni vzorec in podatkovni vir 52

2.3 Opis metod dela 52

3 Rezultati in razprava 53

3.1 Gospodarjevo dojemanje oddaljenosti kmetije 54

3.2 Odločitev gospodarja glede ponovnega prevzema kmetije 54

3.3 Gospodarjevo dojemanje velikosti kmetije $\quad 55$

3.4 Mnenje gospodarja o vitalnosti gozdnega potenciala 56

3.5 Gospodarjevo mnenje o finančni sposobnosti in obremenitvi kmetije 56

3.6 Gospodarjevo mnenje o spremembah obsega opravljenega dela na kmetiji in njene velikosti v prihodnje ter o povečanju prihodkov iz virov na kmetiji v prihodnje $\quad 57$

4 Sklep 58

5 Literatura 58 


\section{Uvod}

Kmetje so edini del družbe, ki mora sam zagotoviti svojo samoobnovo. Na kmetijah se namreč nadzor nad upravljanjem in lastništvo kmetij medgeneracijsko prenašata znotraj družine (Gasson in Erringtonu 1993). Laband in Lentz (1983) menita, da so nasleditve na kmetijah petkrat pogostejše kot pri drugih poklicih ter da so najboljši primer medgeneracijskega prenosa fizičnega in človeškega kapitala. Pri prenosu človeškega kapitala gre za prenos splošnih veščin kmetovanja, kot npr. upravljanja s kmetijskimi stroji, in za prenos specifičnih znanj, ki so značilna za vsako posamezno kmetijo. Prenos človeškega kapitala med generacijami v isti družini pa po mnenju istih avtorjev pomeni tudi njegovo plemenitenje, hkrati pa se s tem povečuje tudi vrednost fizičnega kapitala, tako njegova dejanska vrednost kakor tudi zavedanje o njegovi vrednosti. Avtorja poudarjata, da » takrat, ko se večina mladih šele prične poklicno usposabljati, kmečki otroci, zlasti tisti, ki so določeni ali predvideni za naslednike, že usvojijo številna znanja za delo na kmetiji in njihovo vodenje "(prav tam, 311). Med socializacijo dobi potencialni naslednik na kmetiji natančen vpogled $v$ delo gospodarja in kmečki način življenja nasploh, pridobi si neposredne izkušnje in medgeneracijsko posredovana znanja, hkrati pa razvije do vsega navedenega spoštljiv odnos, zlasti do zemlje kot primarnega vira za preživetje na kmetiji.

Zaradi navedenih značilnosti nasledstva lahko predvidevamo, da ima pri ohranjanju medgeneracijske kontinuitete na kmetijah zelo pomembno vlogo usmerjenost staršev. V tradicionalni, v glavnem še vedno patriarhalni družbi, kot je kmečka, je še zlasti pomembna usmerjenost gospodarjev - njihova stališča, dojemanja in razmišljanja. Kot navaja Tietje (2004) po Neldertu in ostalih (1981), se namreč usmerjenost staršev pogosto prenaša na otroke. Sklepamo lahko torej, da to v Sloveniji še posebej velja za kmetije na hribovskih območjih, ki so imele v primerjavi z dolinsko-ravninskimi predeli več stoletij specifičen razvoj, ki je temeljil predvsem na avtarkičnosti kmetij in zaprtosti kmečke družbe. Po mnenju Hribernika $(1993,254)$ se namreč » isti socialni sistem reproducira zlasti, če je tradicionalna kmečka družba notranje socialno slabo diferencirana in če prevladuje patina preteklosti nad sedanjostjo in prihodnostjo, ki se v procesu socializacije nenehno reproducira, kmečka kultura pa neposredno prenaša iz roda v rod «. Namen prispevka je, da postavljeno hipotezo dokažemo, in če se izkaže kot resnična, tudi ocenimo, kakšen pomen imajo dojemanja in mnenja (percepcije) gospodarjev za obstoj in prihodnji razvoj slovenskih hribovskih kmetij.

Percepcija je psihološki proces, pri katerem posamezniki interpretirajo informacije iz okolja in si na njihovem temelju oblikujejo lastno sliko o svetu. Ker se percepcije običajno znatno razlikujejo od objektivne stvarnosti in ker močno vplivajo na vedenje ljudi, vedenje ni zasnovano na stvarnosti sami, temveč na percepciji tega, kar je stvarnost $\mathrm{v}$ resnici (Treven 1998). Zamisel o domnevni povezanosti med percepcijami gospodarja in medgeneracijsko kontinuiteto izhaja iz raziskave, ki smo jo opravili v okviru doktorskega študija (glej Kerbler 2007), in katere rezultate smo predstavili tudi v prispevku Vpliv dejavnikov socialnogeografske strukture hribovskih kmetij v Sloveniji na stanja in odločitve glede nasleditve na njih (glej Kerbler 2008). Z raziskavo smo ugotovili, kateri dejavniki socialnogeografske strukture kmetije vplivajo na nasledstvo na njej in kateri ne. Na predavanjih, ki so sledila, smo rezultate predstavili širši javnosti, zlasti kmetom in kmetijskim svetovalcem. Ob tem se je razvila obširna razprava. Skozi njo so, med dejavniki, za katere smo ugotovili, da so za nasledstvo na kmetiji pomembni, našo pozornost pritegnili tisti, ki izražajo dojemanja in mnenja gospodarjev o strukturi njihovih kmetij. Domnevati smo začeli, da imajo ti dejavniki pri nasledstvu na kmetijah večjo vlogo, kot smo jim jo ob koncu raziskave pripisali, in da je pri tem njihov pomen celo večji, kot pomen drugih dejavnikov. Iz pregleda svetovne in domače literature smo ugotovili, da razmerja med temi dejavniki in drugimi, ki naj bi vplivali na nasledstvo, še niso bili raziskani. Naša domneva in naša spoznanja, ki jih predstavljamo v tem prispevku, so torej edinstveni.

\section{Metode}

\subsection{Izbor dejavnikov in opredelitev terminov}

Vlogo gospodarjevih dojemanj in mnenj za ohranjanje medgeneracijske kontinuitete na hribovskih kmetijah v Sloveniji smo ugotavljali na podlagi vplivov naslednjih dejavnikov:

- gospodarjevega dojemanja oddaljenosti kmetije;

- gospodarjevega mnenja, ali bi se ponovno odločil, da bi prevzel kmetijo in na njej gospodaril, če bi imel to možnost; 
- gospodarjevega mnenja o spremembah obsega opravljenega dela na kmetiji v prihodnje;

- gospodarjevega dojemanja velikosti kmetije;

- gospodarjevih predvidevanj o spremembah velikosti kmetije v prihodnje;

- gospodarjevega mnenja o vitalnosti gozdnega potenciala;

- gospodarjevega mnenja o tem, ali se bodo v prihodnje na kmetiji najbolj povečali prihodki iz virov na kmetiji;

- gospodarjevega mnenja o finančni sposobnosti kmetije za vlaganje v nadaljnji razvoj;

- gospodarjevega mnenja o obremenitvi kmetije za nadaljnji razvoj zaradi najetih kreditov in drugih finančnih bremen.

Dejavnike smo izbrali med 45 dejavniki, kolikor jih je bilo vključenih v celotno raziskavo, pri čemer je šlo za dejavnike poselitvene, posestne, demografske, proizvodne (ekonomske), tehnične in razvojno-inovativne strukture vsake posamezne kmetije (glej Kerbler 2007). Zanimalo nas je, kako dejavniki vplivajo na stanja glede nasleditev na kmetijah in odlocitve, povezane s prevzemi/predajami kmetij. Prvo pomeni, ali je na kmetiji že oziroma ali bo kot naslednik določena/predvidena oseba, ki bo za gospodarjem zagotovo v celoti prevzela nadzor nad upravljanjem in vodenjem kmetije ter bo postala tudi gospodar in lastnik kmetije. Drugo se nanaša na to, ali se je ta oseba že odločila, da bo gospodarja nasledila, in ali se je odločila tudi, da bo nadaljevala s kmetovanjem po prevzemu kmetije.

\subsection{Raziskovalni vzorec in podatkovni vir}

Da bi bile ugotovitve čim pomembnejše, struktura kmetij pa čim bolj homogena, smo za ugotavljanje vplivov oblikovali ciljno skupino hribovskih kmetij, ki so si morale biti med seboj čim bolj podobne. Izbrali smo jih na podlagi teh kriterijev:

- biti so morale v alpski ali predalpski Sloveniji;

- njihova glavna proizvodna usmeritev je morala biti živinoreja;

- gospodarji kmetij so morali bili stari vsaj 45 let.

Zadnji kriterij smo izbrali, ker postanejo vprašanja glede nasledstva na kmetiji pomembna za gospodarjeve načrte šele, ko je gospodar star 45 let. Predvideni nasledniki gospodarja, če so njegovi potomci, so namreč takrat že stari toliko, da se do načrtov in predvidevanj gospodarja do nasledstva na kmetiji lahko sami opredelijo in glede tega sprejemajo odločitve. Potter in Lobley (1992) ugotavljata, da mlajši gospodarji večinoma pričakujejo, da bo na njihovih kmetijah v prihodnosti prišlo do nasleditve, ne glede na to, ali za to že obstajajo realne osnove. Hkrati pa ista avtorja (Potter in Lobley 1996a) tudi navajata, da večina gospodarjev, ki so mlajši od 45 let, meni, da je o nasledstvu na kmetijah in načrtih v zvezi s tem še prezgodaj govoriti. Kot ugotavljajo Weiss (1999), Kimhi in Bollman (1999) ter Juvančič (2002), se verjetnost opustitve kmetije do 43., 44. oziroma 45. leta gospodarjeve starosti celo zmanjšuje, nato pa se stalno povečuje. Weiss (1999) povezuje to $z$ »učinkom življenjskega cikla«. Te ugotovitve potrjujejo, da je bila odločitev, da se v vzorec vključi samo gospodarje kmetij, ki so stari 45 let in več, pravilna.

Ker statistične službe ne nudijo vseh podatkov, ki smo jih potrebovali za raziskavo, smo jih pridobil $\mathrm{z}$ anketiranjem. Končni raziskovalni vzorec za preučitev vplivov izbranih dejavnikov je zajemal 789 hribovskih kmetij ali 11,6\% vseh hribovskih kmetij, ki smo jih na podlagi kriterijev opredelil kot ciljno skupino. Da je raziskovalni vzorec kljub nizkemu deležu reprezentativen, je razvidno iz primerjave podatkov nekaterih osnovnih značilnosti vzorca s podatki, ki veljajo za vse hribovske kmetije ciljne skupine (pri teh kmetijah gre za podatke, ki so bili pridobljeni s popisom kmetij leta 2000). Povprečno so gospodarji na vzorčnih hribovskih kmetijah stari 60,9 let, vsi gospodarji ciljne skupine pa v povprečju 60,4 leta. Gospodarjev moškega spola je v obeh primerih tri četrtine, zelo majhne pa so razlike tudi v povprečni velikost kmetije kmetije raziskovalnega vzorca so v povprečju velike 21,7 hektarja, vse kmetije ciljne skupine pa 20,6 hektarja. Rezultate svoje raziskave smo zato v nadaljevanju posplošili na vse hribovske kmetije v Sloveniji, ki ustrezajo kriterijem ciljne skupine.

\subsection{Opis metod dela}

Domnevno povezanost med percepcijami gospodarja in medgeneracijsko kontinuiteto ter jakost teh povezav smo ugotavljali s pomočjo posebnih regresijskih modelov, imenovanih modeli diskretne izbire - izraz 
smo prevzeli po Greenu (2003), ki te modele imenuje tudi modeli kvalitativnega odziva. V nasprotju s klasičnimi linearnimi regresijskimi modeli (izraz je povzet po Gujaratiju (1995)) omogočajo izbrani modeli vpogled v kavzalne zveze med pojasnjeno, odvisno spremenljivko $\left(Y_{i}\right)$ in eno ali več pojasnjevalnimi, neodvisnimi spremenljivkami $\left(X_{1} \ldots X_{k}\right)$, tudi če ne poznamo zveznih, kvantitativnih vrednosti odvisne spremenljivke, ampak ločimo le končno število izidov, ki zavzemajo diskretne, kvalitativne vrednosti (Bajt in Štiblar 2002; Maddala 1999; Wooldridge 2002). Fox (1997) navaja, da je za regresijske modele značilno, da lahko na podlagi sprejetega modela in ocen njegovih parametrov iz vrednosti pojasnjevalnih spremenljivk napovemo vrednost odvisne spremenljivke, medtem ko modeli diskretne izbire - kot verjetnostni modeli - omogočajo napovedovanje verjetnosti odziva, izbire oziroma verjetnosti uresničitve dogodkov (Liao 1994; Wooldridge 2002). Greene (2003) pojasnjuje to z zapisom:

$\operatorname{Prob}(\operatorname{dogodek} j$ se zgodi $)=\operatorname{Prob}(Y=j)=P($ relevantni učinki, parametri $)$

Pri tem pomeni Prob $(Y=j)$ verjetnost, da se bo dogodek $j$ pri danih $X_{i}$ zgodil, dogodek pa posameznikovo izbiro med alternativami - izidi, ki jih zavzema odvisna spremenljivka $Y_{i}$.

V raziskavi smo omejili na dva izida odvisne spremenljivke $Y_{i^{*}}$ Gre za dogodka, ki sta povezana s prevzemi kmetij in nadaljnjim kmetovanjem na njih:

$Y_{i}=1 \quad$ kmetijo bo prevzel naslednik, ki se bo še naprej ukvarjal s kmetovanjem;

$Y_{i}=0 \quad$ na kmetiji ne bo prišlo do nasleditve oziroma kmetijo bo prevzel naslednik, ki se ne bo ukvarjal s kmetovanjem.

Vsaki od 789-ih kmetij raziskovalnega vzorca je ustrezal en izid odvisne spremenljivke $Y_{i}$, in sicer je izid $Y_{i}=1$ ustrezal 481-im kmetijam, kar je $60,9 \%$ vzorčnih kmetij, izid $Y_{i}=0$ pa 308-im kmetijam, ker pomeni $39,1 \%$. Algoritem za njihovo razvrščanja v skupini je podrobneje opisan in predstavljen v enem od avtorjevih objavljenih prispevkov (glej Kerbler 2008a).

Ker zavzema odvisna spremenljivka $Y_{i}$ dva izida, smo za izvedbo modela diskretne izbire - torej oceno vplivov izbranih dejavnikov kot pojasnjevalnih spremenljivk na odvisno spremenljivko $Y_{i}$-izbirali med dvema metodološkima pristopoma: logističnim in probit modelom binarne izbire. Po Gujaratiju (1995) je izbira odvisna predvsem od računalniške programske opreme, ki je raziskovalcu na voljo za analizo. Ob domnevi, da je vzorec preučevanja dovolj velik, se po Maddalaju (1999) rezultati obeh metodoloških pristopov izvedbe modelov binarne izbire tudi ne razlikujejo bistveno. Na podlagi tega smo se odločili za probit model binarne izbire, imenovan tudi normit model. Ker zavzema odvisna spremenljivka dva izi$\mathrm{da}$, gre $\mathrm{v}$ tem primeru za t. i. probit modele binarne izbire. Izvedli smo jih $\mathrm{z}$ računalniškim programom LIMDEP 7.0, ki je bil izdelan posebej za izračunavanje linearnih in nelinearnih regresijskih modelov.

\section{Rezultati in razprava}

Rezultati empirične analize so pokazali, da so dejavniki, ki izražajo dojemanja in mnenja gospodarjev, za stanja in odločitve glede nasleditve na hribovskih kmetijah zelo pomembni. V primerjavi z drugimi dejavniki, ki so bili zajetimi v raziskavo (glej Kerbler 2008b), je namreč jakost izbranih dejavnikov v skoraj vseh primerih izrazita (preglednica 1).

Preglednica 1: Jakost izračunanih vplivov dejavnikov, ki izražajo dojemanja in mnenja gospodarjev.

\begin{tabular}{lc}
\hline dejavniki, ki izražajo dojemanja in mnenja gospodarjev & jakost vpliva \\
\hline gospodarjevo dojemanje oddaljenosti kmetije & izrazit \\
gospodarjevo mnenje, ali bi se še enkrat odločil, da bo prevzel kmetijo in na njej gospodaril, če bi imel to možnost & izrazit \\
gospodarjevo mnenje o spremembah obsega opravljenega dela na kmetiji v prihodnje & izrazit \\
gospodarjevo dojemanje velikosti kmetije & zmeren \\
gospodarjevo mnenje o spremembah velikosti kmetije v prihodnje & izrazit \\
gospodarjevo dojemanje vitalnosti gozdnega potenciala & velik \\
gospodarjevo mnenje, da se bodo v prihodnje na kmetiji najbolj povečali prihodki iz virov na kmetiji & izrazit \\
gospodarjevo mnenje o finančni sposobnosti kmetije za vlaganje v nadaljnji razvoj & izrazit \\
gospodarjevo mnenje o obremenitvi kmetije za nadaljnji razvoj zaradi najetih kreditov in drugih finančnih bremen & izrazit \\
\hline
\end{tabular}

Opomba: Jakost vpliva posameznega dejavnika je določena na podlagi $t$-vrednosti izračunanih povezav. 
Pomembnost izbranih dejavnikov se še nazorneje kaže, če $t$-vrednosti razdelimo v razrede in pretvorimo v lestvico od 1 (ni vpliva) do 5 (izrazit vpliv) ter izračunamo povprečno vrednost jakosti vplivov. Povprečna vrednost vplivov za dejavnike, ki izražajo dojemanja in mnenja gospodarjev, je 4,66, povprečna vrednost vplivov za druge dejavnike pa 3,05 .

\subsection{Gospodarjevo dojemanje oddaljenosti kmetije}

Rezultati empirične analize so pokazali, da lega kmetije sicer pomembno vpliva na stanja in odločitve glede nasleditve na kmetiji, vendar je za nasledstvo na njih bolj kot fizična, dejanska (časovno/prostorsko) oddaljenost kmetij (npr. od občinskega središča, osnovne šole, trgovine z osnovnimi živili, zdravnika, veterinarja ali najbližje glavne ceste $\mathrm{v}$ dolini) pomembno, kako oddaljenost dojemajo gospodarji.

Vpliv tega dejavnika je negativen, kar pomeni, da je pri kmetijah, katerih gospodarji menijo, da so oddaljene, odmaknjene od najbližjih administrativnih središč in glavne ceste v dolini, verjetnost, da bo kmetijo prevzel naslednik, ki bo na njej še naprej kmetoval, manjša, in sicer za skoraj 40 odstotnih točk, kot na kmetijah, katerih gospodarji imajo glede lege nasprotno mnenje. $\mathrm{Na} 60,3 \%$ kmetij, katerih gospodarji menijo, da so oddaljene, izolirane, odmaknjene od najbližjih administrativnih središč in glavne ceste v dolini, do nasleditve ne bo prišlo oziroma jih bodo nasledniki prevzeli, vendar se ne bodo ukvarjali s kmetovanjem. Nasprotno bo do prevzema in nadaljnjega kmetovanja prišlo na 79,6\% kmetij, ki jih gospodarji ne dojemajo kot oddaljene, izolirane.

Slika 1: Na hribovskih kmetijah je verjetnost nasleditve večja, če njihovi gospodarji menijo, da kmetije niso odmaknjene oziroma izolirane. Glej angleški del prispevka.

Po drugi svetovni vojni se je $\mathrm{z}$ razvojem osebne motorizacije in izboljšanjem cestne infrastrukture na hribovskih območjih dejanska časovna/prostorska oddaljenost kmetij postopno zmanjševala. Vendar če gospodar kmetijo (kljub temu) dojema kot oddaljeno, zmanjševanje fizične odmaknjenosti nima pomembnejšega vpliva na pogostejše prevzemanje kmetij. To dokazuje tudi podrobnejša analiza anketnih podatkov - za njo smo izbrali kmetije, ki so od občinskega središča oddaljene od 5 do 15 kilometrov, kar velja za dve tretjini vseh preučenih kmetij. Slaba polovica gospodarjev kmetij dojema te kot odmaknjene, druga polovica jih ne dojema tako. Izkazalo se je, da prav njihovo mnenje v večini primerov določa tudi stanje in odločitve glede nasleditve na kmetijah, saj je bila povprečna oddaljenost kmetij v obeh skupinah enaka. Na kmetijah, ki so po mnenju gospodarjev odmaknjene, bo tako prišlo do nasleditve in nadaljnjega kmetovanja le v $41 \%$ primerov, medtem ko je med kmetijami, ki jih gospodarji ne dojemajo kot odmaknjene, takšnih primerov kar $82,2 \%$. Na podlagi teh ugotovitev lahko dopolnimo Hribernikovo (1996) spoznanje, da je na kmetijah, ki so odmaknjene od glavnih prometnih in socialnih komunikacij, verjetnost, da bi se kdo od odseljenih potomcev vrnil na kmetijo, zelo majhna. Po našem mnenju bi bila na kmetijah verjetnost nasleditve večja, če bi njihovi gospodarji menili, da niso odmaknjene oziroma izolirane.

\subsection{Odločitev gospodarja glede ponovnega prevzema kmetije}

Kot navajata Fasterding $(1995,1999)$ in Tietje (2004), izraža gospodarjevo prepričanje, da bi ponovno prevzel kmetijo in na njej gospodaril, če bi imel to priložnost, njegovo zadovoljstvo s poklicem, ki ga opravlja. Izraža tudi njegovo veselje do dela in življenja na kmetiji, njegov spoštljiv odnos do kmetije in ohranjanja dediščine predhodnih generacij. Vse to ima zelo pomemben motivacijski učinek pri pripravah in odločitvah določenega ali predvidenega naslednika za prevzem kmetije, kar potrjujejo tudi rezultati empirične analize. Med kmetijami, katerih gospodarji bi se še enkrat odločili, da bi prevzeli kmetije in na njih gospodarili, je 77,8 \% takšnih, ki jih bodo prevzeli nasledniki in na njih še naprej kmetovali, med kmetijami, katerih gospodarji se za to ne bi odločili, pa je 66,8 \% takšnih, na katerih do nasleditve ne bo prišlo ali pa jih bodo prevzeli nasledniki, ki se ne bodo ukvarjali s kmetovanjem. Zanimiva je tudi ugotovitev, da je med kmetijami, na katerih nasledniki še niso natančno določeni in nihče še ni predviden za to vlogo, njihovi gospodarji pa se za ponoven prevzem kmetije ne bi več odločili, skoraj $84 \%$ takih, katerih gospodarji naslednikov ne bodo iskali, zaradi česar se medgeneracijska kontinuiteta ne bo ohranila. 
Slika 2: Gospodarjevo veselje do dela in življenja na kmetiji ima pomemben motivacijski učinek pri odločitvah določenega ali predvidenega naslednika za prevzem kmetije.

Glej angleški del prispevka.

Pomen zadovoljstva $\mathrm{z}$ delom, ki ga opravljajo na kmetiji, izraža tudi mnenje oziroma razmišljanje mladega gospodarja na hribovski kmetiji. Prevzemnik bo nadaljeval s kmetovanjem. Star je 24 let, ima srednješolsko kmetijsko izobrazbo, v prihodnje želi povečati število živine in načrtuje, da bo kmetijo opremil z novimi stroji in napravami. Predhodni gospodar, njegov oče, bi se brez pomisleka še enkrat odločil, da bi prevzel kmetijo in na njej gospodaril, če bi imel to možnost. Kot dopolnilo k anketi je mladi gospodar napisal: » Na tej kmetiji se dela $z$ veseljem in vztrajno že mnogo let. Zato sem se odločil kot mlad fant za nadaljnjo kmetovanje. Obdelujemo vse, tudi najbolj strme površine. V kolikor se razmere do kmeta ne bodo preveč zaostrile, bom z veseljem nadaljeval. Preveč pod prste gledati kmetu se mi ne dopade in suženj ne mislim postati «

V nasprotju s tem naslednji primer ponazarja, kako lahko ima nezadovoljstvo gospodarja s poklicem, ki ga opravlja, tudi nasprotne učinke. Gospodar je zapisal: » Ne želim nobenemu od svojih otrok ali vnukov tako napornega in skromnega življenja. Samo veselje do narave in živali ne more odtehtati vseh odrekanj in naporov, ki jih prinese življenje na taki hribovski kmetiji «

$\mathrm{Na}$ tej kmetiji naslednik še ni določen in nihče še ni predviden za naslednika, gospodar pa ga tudi ne išče in je prepričan, da ga tudi do takrat, ko bo prenehal gospodariti, ne bo našel in določil. Če bi imel ta gospodar možnost, se nikoli več ne bi odločil za prevzem kmetije in gospodarjenje na njej.

\subsection{Gospodarjevo dojemanje velikosti kmetije}

Raziskovalci, ki so raziskovali vplive dejavnikov na nasledstvo na kmetijah - npr. Kimhi in Lopez (1999) v ameriški zvezni državi Maryland, Stiglbauer in Weiss (2000) v Zgornji Avstriji, Kimhi in Nachlieli (2001) v Izraelu -, so v empirične analize nasledstva običajno vključili velikost kmetije, kar kaže na velik pomen tega dejavnika za nasledstvo. Glauben in ostali (2003) navajajo, da naj bi bila v Nemčiji velikost kmetije $\mathrm{v}$ devetdesetih letih 20. stoletja celo glavni dejavnik pri odločitvah o prenehanju kmetovanja, po Thii Hennessy (2004) pa je velikost kmetije celo pomembnejši dejavnik za ugotavljanje vplivov na stanja in odločitve glede nasleditve na kmetiji kot dohodek na kmetiji. Zadnjenavedeni dejavnik je po njenem mnenju le izraz trenutne, ne pa prihodnje tehnične in gospodarske zmožnosti kmetije. Ugotovitve se ujemajo z dognanji Rosemary Fennell (1981) ter Ruth Gasson in ostalih (1988), ki navajajo, da je eden od glavnih vzrokov, da gospodarjevi otroci ne prevzamejo kmetij, v tem, da so te premajhne. To se potrjuje tudi pri Hriberniku (1996, 16), ki navaja, da » kmetijski proizvodni obrati z nekaj hektari kmetijskih zemljišč ne morejo zagotoviti primerljivega dohodka aktivnim in vzdrževanim članom kmečkega gospodinjstva (še zlasti, če so te kmetije na območjih s težjimi razmerami za kmetovanje, op. av.), s tem pa ne tudi take ravni socialne varnosti, $k i$ bi spodbujala mlade ljudi k ohranjanju kmetijskih gospodarstev kot proizvodnih in posestnih enot. Če so kmetije premajhne, si potencialni nasledniki in drugi clani gospodarjevega gospodinjstva ter morebitnih drugih gospodinjstev na kmetiji poiščejo zaposlitve zunaj kmetije «.

Pomembnost velikosti kmetije pri nasleditvah se je potrdila tudi v naši raziskavi. Ne glede na to, s katerim dejavnikom smo izrazili velikost kmetije - s površino kmetijskih zemljišč v uporabi ali številom živine -, se je izkazalo, da se verjetnost prevzema kmetije in nadaljnjega kmetovanja na njej povečuje, če se povečuje tudi velikost kmetije.

Slika 3: Bolj kot velikost kmetije, izražena v količinskih merah, je za stanja in odločitve glede nasleditve na kmetijah pomembno gospodarjevo dojemanje velikosti kmetije.

Glej angleški del prispevka.

Poleg velikosti kmetije, izražene v količinskih merah, smo v raziskavi domnevali, da je za stanja in odločitve glede nasleditve na kmetijah pomembno tudi gospodarjevo dojemanje velikosti kmetij, česar doslej raziskovalci še niso analizirali. Rezultati empirične analize so potrdili našo domnevo. Verjetnost, da bo kmetijo prevzel naslednik, ki bo na njej tudi nadaljeval s kmetovanjem, se namreč poveča za 26 odstotnih točk, če gospodar meni, da je kmetija velika. Podrobnejša analiza tudi kaže, da bo na eni strani do nasleditve in nadaljnjega kmetovanja prišlo na skoraj četrtini kmetij, ki so sicer manjše od povprečne veli- 
kosti vseh preučenih kmetij, vendar pa njihovi gospodarji kljub temu menijo, da so velike, medtem ko se na drugi strani to ne bo zgodilo na skoraj desetini kmetij, ki so sicer večje od povprečne velikosti vseh preučenih kmetij, vendar njihovi gospodarji menijo, da so majhne.

\subsection{Mnenje gospodarja o vitalnosti gozdnega potenciala}

Natek (1992) ugotavlja, da je poleg živinoreje gozdarstvo najpomembnejša panoga v sestavu gospodarstva za nadaljnji razvoj hribovskih kmetij. Po njegovem mnenju » mnoge hribovske kmetije nikoli ne bi dosegle takšnega napredka, če ne bi imele v zaledju svojega kmetijstva tudi gozdov z bogatimi lesnimi zalogami «(Natek 1983, 251). Navedeno se potrjuje tudi pri Čampi (1992), ki meni, da je les v gozdu že od začetkov svoje komercializacije (od 19. stoletja) dobro naložen kapital oziroma rezerva pri gospodarskih krizah, neuspehih in nesrečah pri kmetovanju, izplačilu dediščin ali zadolžitev. Med splošno krizo ali krizo v kmetijstvu so lahko dohodki od prodaje lesa tudi nadomestilo za dohodkovni deficit kmetijske (živinorejske) pridelave. Na podlagi tega smo predvideli, da ima gozdarstvo pozitiven vpliv na stanje in odločitve glede nasleditve na kmetiji.

Vendar pa so, kot ugotavljajo Robič in ostali (1986), gozdovi na hribovskih kmetijah zaradi velikih finančnih potreb že zelo izsekani. » V polpreteklem obdobju so namreč iz prihodkov gozdov financirali izgraditev cestne mreže, ki je podlaga za intenzivnejše kmetijstvo, neposredno pa so ti dohodki podprli preusmeritev in modernizacijo kmetij « (prav tam, 18). Po našem mnenju je zato za odločitve glede prevzemanja hribovskih kmetij vitalnost gozdnega potenciala pomembnejši kazalec kot površina gozdnih površin ali etat. Vitalnost gozdnega potenciala je namreč dejavnik kvalitativne narave, gre torej za oceno oziroma mnenje o tem, ali je gozd na kmetiji že zelo izsekan ali ne. Na kmetiji je lahko etat visok tudi, če je gozd že zelo izsekan, vendar pa lahko takrat, ko je dosežena zgornja (dovoljena) meja izsekanosti gozda, močno upade. Gozd je sicer obnovljiv naravni vir, vendar je njegova obnova dolgotrajna, zato je ob pogostih in nepredvidljivih gospodarskih nihanjih ogrožen tudi obstoj hribovskih kmetij. Dejavnik vitalnost gozdnega potenciala je bil oblikovan za našo raziskavo in je bil tako prvič uporabljen pri raziskovanju vplivov dejavnikov na nasledstvo na kmetijah.

Slika 4: Hribovske kmetije brez vitalnega gozdnega potenciala pogosto nimajo zagotovljene medgeneracijske kontinuitete. Glej angleški del prispevka.

Rezultati empirične analize so potrdili našo domnevo. Na kmetijah, katerih gospodarji menijo, da je gozd že zelo izsekan, je verjetnost, da jih bodo prevzeli nasledniki, ki bodo tudi nadaljevali s kmetovanjem, za 38,4 odstotne točke manjša kot na kmetijah, katerih gospodarji so prepričani, da je gozdni potencial kmetije še vitalen. Več kot dve tretjini kmetij brez vitalnega gozdnega potenciala nima zagotovljene medgeneracijske kontinuitete, medtem ko jo ima zagotovljeno skoraj tri četrtine kmetij z vitalnim gozdnim potencialom. Podrobnejša analiza je pokazala, da je največ preučenih kmetij z izsekanim gozdom tistih, na katerih so gospodarji naslednike sicer že določili ali predvideli, vendar pa se ti še niso odločili, da bodo kmetije prevzeli, gospodarji pa so glede tega tudi zelo črnogledi in menijo, da se to zagotovo ne bo zgodilo. Zanimiva je še ugotovitev, da ima vitalen gozdni potencial skoraj $82 \%$ kmetij, na katerih naslednikov sicer še nimajo določenih ali predvidenih, vendar pa so gospodarji optimistični in menijo, da bodo njihove kmetije zagotovo ohranile nasledstveno kontinuiteto in bodo nasledniki po prevzemu tudi nadaljevali s kmetovanjem.

\subsection{Gospodarjevo mnenje o finančni sposobnosti in obremenitvi kmetije}

Dejavnik, ki izraža gospodarjevo mnenje o finančni sposobnosti kmetije za vlaganje v nadaljnji razvoj, ter tudi dejavnik, ki izraža njegovo mnenje o obremenitvi kmetije za nadaljnji razvoj zaradi najetih kreditov in drugih finančnih bremen sta zelo pomembna pri odločitvah potencialnih naslednikov za nasleditev na kmetiji. Ugotovitve o smeri vplivov prvega dejavnika se ujemajo z rezultati raziskav Glaubna in ostalih (2004), glede vplivov drugega dejavnika pa z ugotovitvami Glaubna in ostalih (2002), Minne Väre in Weissa (2003) ter Minne Väre in ostalih (2006). Če gospodar meni, da je kmetija finančno sposobna za vlaganje v nadaljnji razvoj, je verjetnost, da ga bo nasledil naslednik, ki bo na kmetiji tudi nadaljeval s kmetovanjem, za 38,6 odstotne točke večja, kot če meni, da kmetija ni finančno sposobna. Tudi verjet- 
nost ohranitve medgeneracijske kontinuitete je manjša, če gospodarji menijo, da so dolgovi zaradi najetih kreditov ali druga finančna bremena prehuda obremenitev za nadaljnji razvoj kmetije.

Zelo pomembno je zlasti spoznanje, da je med kmetijami, ki imajo po mnenju gospodarja dovolj kapitalske moči za nadaljnji razvoj, skoraj tri četrtine takšnih, katerih nasledniki niso le natančno določeni, ampak so se tudi sami že povsem odločili, da bodo kmetije prevzeli in nadaljevali s kmetovanjem. Po drugi strani kar $45 \%$ kmetij, katerih gospodarji menijo, da finančne obremenitve ogrožajo nadaljnji razvoj kmetij, še nima določenih ali predvidenih naslednikov, gospodarji pa tudi ne vidijo nobenih možnosti, da bi naslednike lahko zagotovili. $20 \%$ gospodarjev kmetij s finančnimi obremenitvami pa je svoje naslednike sicer določilo ali predvidelo, vendar so se ti odločili, da kmetij ne bodo prevzeli ali pa po njihovem prevzemu ne bodo nadaljevali s kmetovanjem.

Če torej gospodar ni gotov glede kapitalske moči kmetije in s tem glede njenega prihodnjega razvoja, če ga je strah za nadaljnji razvoj kmetije zaradi finančnih bremen, je ta njegov dvom pomembna informacija za potencialnega naslednika, ki se odloča za poklic. Tudi Ana Barbič $(1993,265)$ ugotavlja, da » mladi, ki v kmetijstvu ostajajo, počnejo to vse manj iz emocionalnih in vse bolj iz ekonomskih razlogov «. Očitno je namreč, da mladi - v nasprotju s svojimi starši - vidijo v kmetiji kapital, ki ga je treba nenehno oplajati, ne pa načina in smisla življenja, torej življenjskega projekta (Kerbler 2003).

Slika 5: Če je gospodar zaskrbljen glede nadaljnjega razvoja kmetije oziroma nima v kmetijo kot primarni vir preživetja zaupanja, je verjetnost prevzema take kmetije in nadaljnjega kmetovanja na njej bistveno manjša, kot če razmišlja gospodar vzpodbudno.

Glej angleški del prispevka.

Po Kovačiču (1995) zahtevajo vse bolj zaostreni pogoji gospodarjenja v kmetijstvu nenehno uvajanje inovacij in prilagajanje proizvodne strukture tržnim zahtevam. V takšnem okolju dosegajo pozitiven razvoj le kmetije, katerih gospodarji so dovolj samozavestni, kreativni, prilagodljivi in samoiniciativni oziroma sledijo inovacijskim procesom. In takšni so običajno mladi ljudje, torej potencialni nasledniki. Če torej mladi, za katere so značilne opisane lastnosti, prejmejo od staršev informacije, da kmetija ni finančno sposobna za vlaganja $v$ prihodnji razvoj, se, kot kažejo podatki izsledki empirične analize, za prevzeme takšnih kmetij običajno ne odločijo.

\subsection{Gospodarjevo mnenje o spremembah obsega opravljenega dela na kmetiji in njene velikosti v prihodnje ter o povečanju prihodkov iz virov na kmetiji v prihodnje}

Vplive teh dejavnikov je treba interpretirati pazljivo. Predvideno spreminjanje obsega opravljenega dela na kmetiji in njene velikosti ter povečanje prihodkov iz virov na kmetiji sta namreč lahko vzroka za stanje in odločitve glede nasleditve na kmetiji oziroma tudi posledici tega. Potter in Lobley (1992), na primer, interpretirata rabo kmetijskih zemljišč kot posledico stanj in odločitev glede nasleditve na kmetiji, ne pa kot vzrok zanje. Po njunem mnenju naj bi namreč stanje in pričakovanja glede nasleditve na kmetiji dolgoročno pomembno določala razvojno smer kmetije ter tudi obnašanja in odločitve gospodarjev (Potter in Lobley 1996b). V razpravah iz let 1992 in 1996 (1996a in 1996b) govorita o učinkovanju treh dejavnikov: 1 - o vplivu nasledstva;

2 - o vplivu naslednika;

3 - o vplivu upokojitve.

Za prva dejavnika gre, če je na kmetiji naslednik določen ali predviden, za tretjega pa, če naslednik še ni določen in tudi nihče za to ni predviden.

1. Vpliv nasledstva naj bi se kazal $\mathrm{v}$ tem, da pričakovanje, da bo do nasleditve prišlo, motivira gospodarje, da sistematično vlagajo v razvoj kmetije. Vpliv nasledstva je največji na kmetijah, na katerih je nasledstvo skrbno načrtovano in se običajno začne ob rojstvu gospodarjevega prvega otroka, okrepi pa se, ko se naslednik tudi sam odloči, da bo kmetijo prevzel.

2. Ko določeni oziroma predvideni nasledniki že prevzamejo del upravljanja na kmetiji, je mogoče govoriti o vplivu naslednika oziroma o vplivu nove krvi. Za mlade prevzemnike je namreč značilno, da so v začetku svoje poklicne poti zelo inovativni, zato so po mnenju Blanca in Perrier-Corneta (1993) gibalo posodabljanja kmetijskih struktur. 
3. Vpliv upokojitve je povezan z gospodarjevo upokojitvijo. Na kmetijah brez naslednikov se namreč po upokojitvi najpogosteje postopoma zmanjša število delovnih ur, zmanjša se površina kmetijskih zemljišč v uporabi in obseg kmetijske pridelave, vse manj pa vzdržujejo tudi stroje in strojno opremo ter objekte, ki so pogosto prazni. Weiss (1999) ter Stiglbauer in Weiss (2000) navajajo po Grilichesu in Regevu (1995), da je pojav značilen za t. i. pogubljena podjetja, pri katerih se na ta način kaže zavedanje o bližajočem se koncu.

Čeprav sta Potter in Lobley (1992) tudi statistično potrdila, da upokojitev gospodarja ter tudi pričakovanje nasleditve in prisotnost naslednika na kmetiji vplivajo na njeno strukturo, sta $\mathrm{v}$ raziskavi večkrat poudarila, da ločitev med vzrokom in posledico ni jasna. Do enakih dilem glede vzročno-posledičnih odnosov so prišli tudi Stiglbauer in Weiss (2000), Kimhi in Nachlieli (2001) ter Glauben in ostali (2004). Kot rešitev za razumevanje vzrokov in posledic so avtorji predlagali širši časovni okvir opazovanja, raziskovanje pa bi moralo biti po njihovem mnenju osredotočeno na spoznavanje življenjska cikla vsake kmetije posebej. Ker bi imela takšna raziskava povsem drugačne cilje, zahtevala pa bi tudi drugačne metode in tehnike raziskovanja, bi, če bi poskušali za vsak preučen dejavnik preveriti, ali je bila njegova opredelitev kot vzrok za stanje in odločitve glede nasleditve na kmetiji upravičena, daleč presegli okvir svoje raziskave. Zato smo sledili večini raziskav, ki se ukvarjajo s preučevanjem verjetnosti nasledstva, ter stanja in odločitve glede nasleditve na kmetijah opredelili kot posledico vplivov različnih dejavnikov, v tem primeru gospodarjevih mnenj o spremembah obsega opravljenega dela na kmetiji in njene velikosti ter o virih prihodkov na kmetiji v prihodnje.

Ne glede na to, katera pojasnjevalna spremenljivka je bila vključena v empirično analizo v naši raziskavi - mnenje glede obsega opravljenega dela, velikosti kmetije ali mnenje glede prihodkov iz virov na kmetiji -, se je izkazalo, da njeno predvideno zmanjševanje izrazito negativno vpliva na stanja in odločitve glede nasleditve na hribovskih kmetijah, medtem ko ima njeno povečevanje izrazito pozitiven vpliv. Najbolj se verjetnost prevzema kmetije zmanjša, če gospodarji menijo, da se bo v prihodnje zmanjšala velikost kmetije, in sicer za 58,3\%, če je velikost izražena $\mathrm{z}$ deležem kmetijskih zemljišč v uporabi, oziroma $62 \%$, če je izražena s številom živine. Med kmetijami, katerih gospodarji predvidevajo povečanje živinorejske proizvodnje, je le 12,6\% takšnih, na katerih do nasleditve ne bo prišlo.

\section{Sklep}

Rezultati in razprava potrjujeta domnevo, da imajo na slovenskih hribovskih kmetijah gospodarjevo dojemanje in njegova mnenja zelo pomembno vlogo pri zagotavljanju medgeneracijske kontinuitete. Vedenjski in miselni vzorci, ki jih potencialni nasledniki v socializacijskem procesu dobijo prek staršev, zlasti gospodarja, ki je vzor potencialnemu nasledniku za njegov prihodnji poklic, se pri medgeneracijskem prenosu kmetovanja zelo dobro ohranjajo. Ugotovili smo, da lahko gospodarji s pozitivno naravnanostjo, spodbudami, z zadovoljstvom in veseljem do dela in življenja na kmetiji ter $\mathrm{z}$ dobrim mnenjem o kmetiji, njeni strukturi, njenem trenutnem in prihodnjem razvoju pomembno vplivajo na odločitve potencialnih naslednikov, da se za prevzeme odločijo in da tudi nadaljujejo s kmetovanjem ter ohranijo medgeneracijsko kontinuiteto, s tem pa omogočijo nadaljnji razvoj in obstoj kmetije. Zato bi država kot ukrep za spodbujanje prevzemanja kmetij, zlasti v hribovskih območjih Slovenije, morala poleg finančnih spodbud širiti med kmečkim prebivalstvom tudi ta, nova spoznanja - torej, da lahko k prevzemanju kmetij veliko pripomorejo gospodarji sami. Spodbujanje potencialnega naslednika, naj postane prihodnji gospodar kmetije, je premalo, gospodarji namreč morajo v to, za kar ga vzgajajo, tudi verjeti.

\section{Literatura}

Glej angleški del prispevka. 